\title{
Oligotrophication of Lake Balaton over a 20-year period and its implications for the relationship between phytoplankton and zooplankton biomass
}

\author{
Gábor Bernát $(\mathbb{D} \cdot$ Nóra Boross · Boglárka Somogyi · Lajos Vörös • \\ László G.-Tóth · Gergely Boros
}

Received: 15 May 2020/Revised: 6 August 2020/Accepted: 10 August 2020/Published online: 20 August 2020

(C) The Author(s) 2020

\begin{abstract}
Lake Balaton, the largest lake in Central Europe, underwent severe eutrophication from the 1960s to the 1990s, due to phosphorus loadings from external anthropogenic sources. The subsequent and complex eutrophication control and lake restoration program resulted in a significant decrease in the external phosphorus loading to the lake. Consequently, Lake Balaton has been returning to its former meso-eutrophic character. In this paper, we explore the long-term dynamics of chlorophyll $a(\mathrm{Chl} a)$ concentration, a proxy for phytoplankton biomass, and zooplankton biomass in Lake Balaton during its reoligotrophication period from 2001 to 2017, and attempt to draw some conclusions on the subsequent changes in the fish stock. We found a proportional decrease in zooplankton and phytoplankton biomasses at moderate phytoplankton levels. However, below a certain phytoplankton concentration $\left(<10 \mu \mathrm{g} \mathrm{l}^{-1} \mathrm{Chl}\right.$ $a)$, the decrease in phytoplankton biomass was not coupled with a further decline in zooplankton biomass because the fraction of small phytoplankton, edible for
\end{abstract}

Handling editor: Judit Padisák.

Lajos Vörös, László G.-Tóth, and Gergely Boros: contributed equally to this work.

G. Bernát $(\bowtie) \cdot N$. Boross $\cdot$ B. Somogyi ·

L. Vörös · L. G.-Tóth · G. Boros

Centre for Ecological Research, Balaton Limnological Institute, Klebelsberg Kuno u. 3, 8237 Tihany, Hungary

e-mail: bernat.gabor@okologia.mta.hu zooplankton, showed a much smaller decrease in biomass compared with large non-edible phytoplankton. Thus, improvements in water quality (i.e., reduced nutrient loading), partly via concomitant changes in the phytoplankton size distribution, did not cause a large difference in the fish stock in this shallow lake.

Keywords Shallow lake $\cdot$ Trophic state $\cdot$ Algal size distribution · Inverted pyramid

\section{Introduction}

Eutrophication control is one of the foremost challenges in protecting freshwater ecosystems worldwide (Vollenweider \& Kerekes, 1982; Schindler, 2006). By contemporary definition, eutrophication is an excessive, mostly undesired algal (or plant) growth in aquatic ecosystems, due to the increased availability of one or more limiting factors. Phosphorus acts as an important limiting nutrient in both freshwater and marine systems, and an increase in either the external or internal phosphorus input is primarily responsible for algal blooms in most cases. Human activities contribute extensively to the increase of phosphorus load into aquatic ecosystems and accelerate the rate and extent of eutrophication through both point-source discharges and non-point loadings (Schindler, 2006). Eutrophication may have negative impacts on food/fishing industry and security, tourism, human 
and ecosystem health, and quality of drinking water sources (Ngatia \& Taylor, 2018).

Lake Balaton, the largest lake in Central Europe, underwent severe eutrophication from the 1960s to the 1990s, due to phosphorus loadings from external anthropogenic sources (Hajnal \& Padisák, 2007; Istvánovics et al., 2007). By the peak period of eutrophication, both maximal- and annual mean phytoplankton biomass increased by an order of magnitude, compared to the pre-eutrophication levels (Herodek, 1986; Hajnal \& Padisák, 2007; Istvánovics et al., 2007). The social and economic impacts of the water quality deterioration initiated a complex process of eutrophication control and lake restoration program in the 1980s. It included (i) the reconstruction of the Kis-Balaton Water Protection Reservoir system (wetland), (ii) sewage direction from the watershed, and (iii) introduction of new wastewater treatment methods for phosphorus removal (Istvánovics et al., 2007). Moreover, agriculture had collapsed after the political transition in 1989-1990, leading to a drop in fertilizer usage which further decreased the external phosphorus loading to Lake Balaton. Before the eutrophication management program (i.e. in the 1980s), the average total external phosphorus loading to the lake was $289 \pm 45 \mathrm{t} \mathrm{year}^{-1}$, which has decreased to $145 \pm 47 \mathrm{t} \mathrm{year}^{-1}$ by 2002 (Istvánovics et al., 2007). As a result of the decline in external nutrient loadings, the lake has been returning to its former meso-eutrophic character (Istvánovics et al., 2007; Dokulil et al., 2014).

A comprehensive investigation of the long-term trends in phytoplankton blooms using data from 71 large lakes (Ho et al., 2019) revealed that such a decrease in bloom intensity, which has happened in Lake Balaton since the 1990s (Istvánovics et al., $2007)$, is relatively rare, and it was observed in only $8 \%$ of the lakes studied. The explanation of the few deviations from the general global trend was that lakes with decreasing bloom intensities warmed up to a less extent than the other studied lakes or, such as Lake Balaton, even showed a considerable decreasing trend in summer temperatures. Thus, future global warming, which presumably leads to elevated lake temperatures, will expectedly negatively affect water quality (Mooij et al., 2007) and, in turn, may lead to an increase in bloom intensities. This vulnerability highlights the importance of a better understanding of re-oligotrophication and associated changes in shallow lakes.
Importantly, many aspects of the recovery in the trophic state of Lake Balaton (as well as other shallow lakes), including its impact on food web dynamics, have not yet been investigated in sufficient detail.

Analyzing large datasets obtained from various lakes is a general tool in limnology for ecological, biological, hydrological, and biogeochemical characterization and/or classification of lakes, as well as for predicting future changes. Another, less widespread but still relevant approach is to use long-term datasets obtained from the same lake/sampling site(s) for describing ecological trends. There are only a few examples worldwide for such long-term datasets on a given ecosystem that cover several decades, with consistent sampling protocols and sufficient sampling intensity (see e.g. Nõges et al., 2010; Gsell et al., 2015). The ecological history of Lake Balaton, for example, is among the best documented ones in this respect. Both phytoplankton- and zooplankton biomass data, along with a set of various physicochemical data have been collected for several decades across the longitudinal axis of the lake, with a standardized sampling protocol since 1997 (see "Methods" section).

Interrelationships between phyto- and zooplankton biomass and the regulatory forces affecting these communities are key attributes in shaping the productivity of aquatic ecosystems. Both theoretically (Danielsdottir et al., 2007; Hart, 2011) and empirically (see, e.g. Karjalainen et al., 1996 and references therein), there are several possible scenarios how phytoplankton and zooplankton biomass may interact at a given nutrient level. Besides some abiotic factors, such as temperature and concentration of suspended sediment particles, which have also strong influence on zooplankton growth, zooplankton biomass is largely determined by the interplay of bottom-up and top-down biological forces, i.e. food availability and composition, and predation by fish, respectively (see e.g. Benndorf et al., 2002; Danielsdottir et al., 2007; Yuan and Pollard, 2018). Increasing food concentration for zooplankton (i.e., planktonic eutrophication) often induce a decline in the zooplankton-to-phytoplankton biomass ratios, due to elevated grazing pressure on zooplankton and/or a decline in food quality (McCauley \& Kalff, 1981; Hart, 2011). Conversely, oligotrophication is expected to cause an increase in the zooplankton-to-phytoplankton biomass ratio, a scenario which is well supported by 
the available data (Jeppesen et al., 2005). High food quality involves a suppression of phytoplankton biomass by grazing. In contrast, low food quality results in trophic decoupling at the phytoplanktonzooplankton interface with phytoplankton biomass determined primarily by nutrient availability. Thus, food quality (i.e. phytoplankton composition) is a key factor for determining phytoplankton biomass. On the other hand, food quality and zooplanktivory interact to determine zooplankton biomass at a given nutrient level. Low food quality makes the zooplankton susceptible to over-exploitation, while high algal food-quality allows the zooplankton community to sustain relatively high biomass and to withstand fish predation (Danielsdottir et al., 2007). In shallow lakes, nevertheless, due to the potentially strong linkages between the benthic and pelagic communities, the relationship between phytoplankton and zooplankton biomass might even be more complex and less predictable. In addition, lakes with high inorganic turbidity and high turbulence intensity often lack large-sized zooplankters (G.-Tóth, 1992; Peters \& Marassé, 2000; G.-Tóth et al., 2011), which may also influence grazing pressure on phytoplankton, and eventually the zooplankton-phytoplankton interrelationship. Thus, collecting and analyzing empirical data is an indispensable approach for exploring the phytoplankton-zooplankton interrelationship in turbid, shallow lakes, especially under changing environmental conditions. Our long-term dataset on phytoplankton and zooplankton biomass and composition during re-oligotrophication of Lake Balaton, therefore, is a valuable tool for understanding various aspects of this process. In this paper, we explore the long-term dynamics of chlorophyll $a(\mathrm{Chl} a)$ concentration, a proxy for phytoplankton biomass, and zooplankton biomass, as well as their interrelationship in Lake Balaton during its re-oligotrophication period from 1997 to 2017. The size structure of phytoplankton communities in terms of their edibility by zooplankton (i.e. size) is an important issue to consider while exploring the dependence of zooplankton biomass on phytoplankton biomass (both in general and in particular), it is an important issue that phytoplankton communities show heterogeneity in terms of their edibility by zooplankton (i.e. size). It is generally thought that zooplankton feed most heavily on phytoplankton of 5 to $25 \mu \mathrm{m}$ in size (see e.g. Levine et al., 1999); this was also shown for planktonic cladocerans and herbivorous copepods living in Lake Balaton (G.-Tóth et al., 1987). Hence, we sought to determine whether the size distribution of phytoplankton (i) changed during oligotrophication of Lake Balaton, and, if so, (ii) did it change in favor of phytoplankton species in the edible range $(<25 \mu \mathrm{m}$ in size). Based on our findings we provide some inferences on the consequent changes in the fish stock.

\section{Methods}

Study site

The study area, Lake Balaton $\left(46^{\circ} 62^{\prime}-47^{\circ} 04^{\prime} \mathrm{N}, 17^{\circ}\right.$ $15^{\prime}-18^{\circ} 10^{\prime} \mathrm{E}$ ), is situated in the western (Transdanubian) part of Hungary. Lake Balaton has a surface area of $596 \mathrm{~km}^{2}$, a mean depth of $3.2 \mathrm{~m}$, and a catchment area of $5,775 \mathrm{~km}^{2}$. The total water volume is $1.9 \mathrm{~km}^{3}$, and water retention time is about 4 to 6 years. Typologically, it is a shallow, calcareous lake with moderate salinity, and characterized by high mineral turbidity, high wind-induced turbulence intensity, electrical conductivity range of $700-900 \mu \mathrm{S} \mathrm{cm}^{-1}$, and pH range of 8.4-8.8 (G.-Tóth et al., 2011; Bolgovics et al., 2017; Szabó-Tugyi et al., 2019). Lake Balaton displays an elongated shape with a maximal length of $78 \mathrm{~km}$ and a mean width of $7.7 \mathrm{~km}$, and is oriented along a southwest-northeast direction (Fig. 1). The lake has more than 50 inflows. Its largest tributary, the River Zala, flows through the KisBalaton Reservoir before entering the western basin, and accounts for about $50-60 \%$ of the total annual water supply to the lake. Lake Balaton is discharged via the Sió-Canal, which outflows at the eastern basin. The lake can be divided into four main basins, with increasing mean depths and areas, and decreasing catchment areas from west to east (Fig. 1; Istvánovics et al., 2007). These characteristics implicate several consequences, including a definite trophic gradient along the longitudinal axis of the lake (see "Results" section; Vörös et al., 2009; Felföldi et al., 2011; Ho et al., 2019). Besides its ecological value (the lake is a designated Natura 2000 and Ramsar area), Lake Balaton is a major recreational area, visited by millions of tourists every year. 
Fig. 1 Map of Lake Balaton with standard sampling points (crosses). Division of the lake into four basins is also indicated

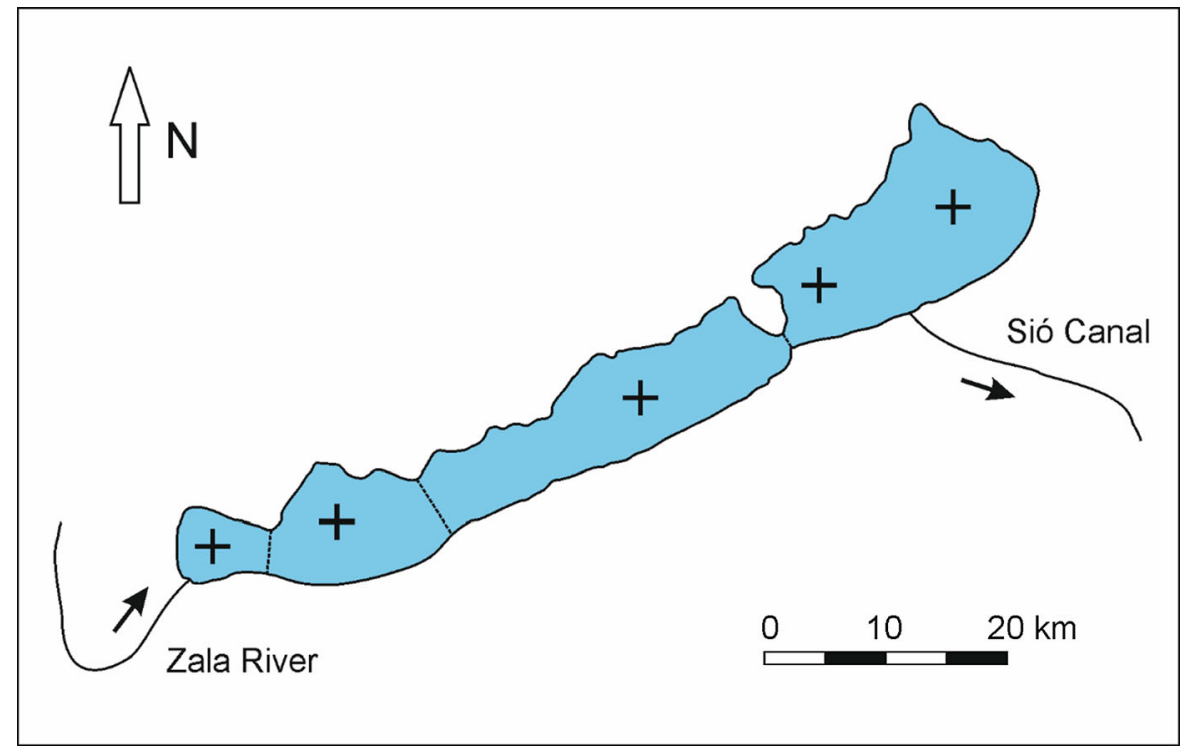

\section{Sampling}

Phytoplankton and zooplankton samples were collected regularly with a biweekly or monthly sampling frequency, between 2001 and 2017, and 1999 and 2017, respectively, from April to October. For the western and eastern basins, additional phytoplankton data are available from 1997 (see "Results" section). Samples were taken at five different standard locations, representing the four main basins along the longitudinal axis of the lake (from west to east: $\mathrm{N} 46^{\circ}$ 44.095' E17 ${ }^{\circ} 16.583^{\prime}$, N46 ${ }^{\circ} 45.112^{\prime}$ E17 ${ }^{\circ} 25.145^{\prime}$, $\mathrm{N} 46^{\circ} 50.661^{\prime} \quad \mathrm{E}^{\circ} 7^{\circ} \quad 44.595^{\prime}, \quad \mathrm{N} 46^{\circ} \quad 55.327^{\prime}$ E17 ${ }^{\circ}$ $55.649^{\prime}$, and $\left.\mathrm{N} 46^{\circ} 59.157^{\prime} \mathrm{E} 18^{\circ} 04.747^{\prime}\right)$. Due to its surface area and spatial heterogeneity, there were two designated sampling sites in the eastern basin (Fig. 1, see also, e.g. G.-Tóth et al., 2011). Phytoplankton samples were collected using a $3.5 \mathrm{~m}$ long tube sampler (inner diameter: $50 \mathrm{~mm}$ ), providing representative samples of the entire water column. Metazoan zooplankton (all planktonic invertebrates, except protozoans) were collected at every $0.5 \mathrm{~m}$ depth from the surface to the sediment (i.e., representing the whole water column: 5-8 samples in total, equivalent to 170 to 2721 of lake water) using a 34-1 SchindlerPatalas-sampler (height: $50 \mathrm{~cm}$ ), equipped with a $40 \mu \mathrm{m}$ pore-sized funnel-trap. To obtain single, homogenous samples, the set of concentrated zooplankton samples taken from various depths at the same location were pooled and filtered through the funnel-trap again, resulting a final sample volume of $250 \mathrm{ml}$. Freshly collected and unpreserved phytoplankton samples were transported to the laboratory within $2 \mathrm{~h}$ in a dark container, while zooplankton samples were preserved on site using either neutralized formalin (3\% final concentration) or Patosolv ${ }^{\circledR}$ (mixture of 85-90\% ethanol and 10-15\% 2-propanol; $70 \%$ final concentration).

Determination of biomass and taxonomic composition of phyto- and zooplankton

Phytoplankton biomass was determined either by converting Chl $a$ concentration data to biomass using literature conversion factors or determining biovolumes directly by microscopy, or both. The former method is widely used in limnology, while the latter one is much less widespread, partly due to its timeconsuming nature (as well as the need of specific expertise). Due to this reason, although we have both types of datasets with similar results, Chl $a$ data was primarily used as a proxy for phytoplankton biomass.

For measuring Chl $a$ concentration, 0.5-1.0 1 of lake water was filtered through GF-5 glass fiber filters (Macherey-Nagel, Düren, Germany), from which pigments were extracted using hot methanol. The Chl $a$ concentration of the pigment extracts was determined spectrophotometrically using a Hitachi U-2900 dual-beam spectrophotometer (Hitachi, Tokyo, Japan) according to Wetzel \& Likens (2000). 
Chl $a$ concentrations were converted to phytoplankton dry weight, taking into account that Chl $a$ content represented about $0.55 \%$ of the wet weight of phytoplankton during the study period (c.f. Kasprzak et al., 2006 and references therein) and a conversion factor of 5.0 between its dry and wet weight. Nano$(2.0-20 \mu \mathrm{m})$ and microplankton $(20-200 \mu \mathrm{m})$ in the collected samples were fixed with Lugol's solution. The composition and abundance of these fractions were determined using an IX 73 Olympus inverted microscope (Olympus, Tokyo, Japan) according to the method of Utermöhl (1958). Separately, the abundance and composition of the pico-fraction $(0.2-2.0 \mu \mathrm{m})$ of phytoplankton was determined using fresh, unpreserved samples according to (MacIsaac \& Stockner, 1993). Briefly, samples were concentrated on black cellulose-acetate filters (Macherey-Nagel, pore size: $0.4 \mu \mathrm{m}$ ), which were subsequently embedded into $50 \%$ glycerol on a microscope slide. The slides were examined using an Olympus BX51 epifluorescence microscope at $\times 1,000$ magnification equipped with blue-violet (U-MWBV2) and green (UMWG2) fluorescence filter cubes. Twenty fields ( $\sim 400$ cells) were photographed using an Olympus DP71 CCD camera and cells were counted on the images to avoid fluorescence fading. The sizes of algal/cyanobacterial cells from different fractions (i.e., picoplankton, nanoplankton, and microplankton) were determined and their volumes were calculated accordingly. The total bio-volume of individual cells and, after summing up, the entire fractions were converted to wet weight (biomass) by assuming a specific density of $1.0 \mathrm{~g} \mathrm{~cm}^{-3}$.

The taxonomic composition, individual density and biomass of the preserved zooplankton samples were analyzed using a Zeiss-Opton inverted microscope ( $\times 80-\times 200$ magnification; Carl Zeiss, Oberkochen, Germany), by counting at least 600 individuals per sample, which resulted in a less than $6 \%$ counting error (Lund et al., 1958). Biomass of individual zooplankton, classified by taxonomy, sex and size (age), were calculated using literature conversion factors (see, e.g. Odermatt, 1970; Dumont et al., 1975; Ponyi \& Zánkai, 1982; Padisák \& Adrian, 1999, and references therein) and were expressed as dry weight.
Statistical analysis

We calculated mean monthly values for Chl $a$ concentration, a direct proxy for phytoplankton biomass, and the total summarized zooplankton biomass from April to September over the period 2001-2017, with both phytoplankton and zooplankton data available. By restricting the data to the April to October periods, uncertainties, introduced by variations in length of the sampling season, were avoided. The mean values over the April to October periods were somewhat higher as compared to the corresponding annual values in all basins, due to most of the data were obtained between April and October and phytoplankton biomass is usually the lowest in winter. Initially, five individual datasets, representing the five standard sampling locations along the longitudinal axis of the lake, were considered (see above and Fig. 1). However, as the data obtained from the two westernmost and also from the two easternmost sampling points, respectively, did not differ statistically, we evaluated them together in the analyses and distinguished only three basins along the longitudinal axis of Lake Balaton: the western, the middle, and the eastern basin.

Statistical analyses were performed using the $\mathrm{R}$ statistical environment (version 3.3.2; R Core Team, 2016). We tested the effect of basin as well as year on the mean Chl $a$ concentration and on the mean zooplankton biomass of each year, by applying General Linear Models. In order to achieve a normal distribution we log transformed zooplankton biomass data. Two separate models were used, including either Chl $a$ or zooplankton biomass concentration as the dependent variable, while the predictor variables were basin and year. To test the influence of phytoplankton biomass on zooplankton biomass, we included $\mathrm{Chl}$ $a$ as a predictor variable. The significance of the predictor variables was determined by the Type II analyses of variance table using the "Anova" function from the "car" R package (version 3.0-2; Fox \& Weisberg, 2011). 


\section{Results}

Temporal trends in Chl $a$ concentration and zooplankton biomass during oligotrophication

The oligotrophication of Lake Balaton during the study period was characterized by a significant decrease in Chl $a$ concentration. The declining trend was typical in all basins. Most of the data collected from the western basin displayed a scatter between 5 and $25 \mu \mathrm{g}^{-1} \mathrm{Chl} a$, however, there were also repetitive spikes on top (highlighted by red dashed line; Fig. 2A). These spikes, representing the late summer maxima in Chl $a$ concentration each year, also showed a decreasing trend during the study period. Likewise, the calculated annual mean values (Fig. 2B, black), as well as mean values over the April to October periods (Fig. 2B, red) exhibited a clear declining trend, indicating an overall decrease in phytoplankton biomass during oligotrophication. By

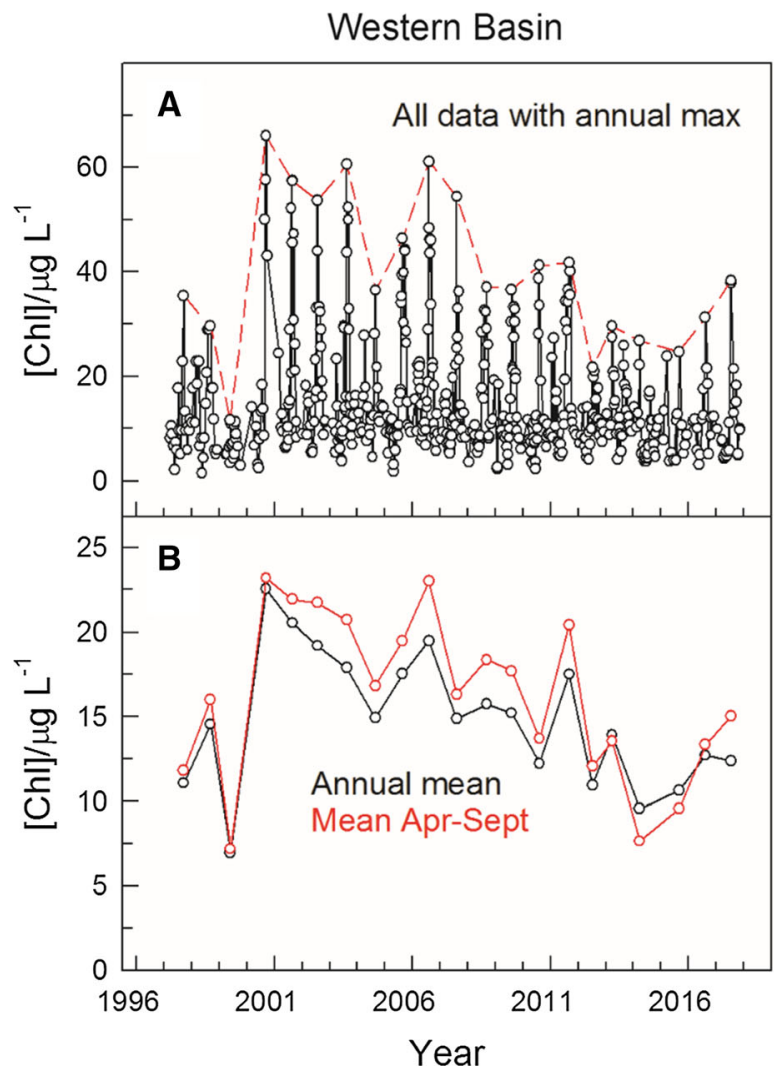

Fig. 2 Changes in chlorophyll a concentration, a proxy for phytoplankton biomass, in the western $(\mathbf{A}, \mathbf{B})$ and eastern basin (C, D) of Lake Balaton from 1997 to 2017. While panels A and the end of the study period (i.e. 2013 to 2017), this basin clearly showed a meso-eutrophic character (Wetzel, 2001) with about $12 \mu \mathrm{g} \mathrm{l}^{-1}$ mean Chl $a$ concentration.

Most individual $\mathrm{Chl} a$ data from the oligo-mesotrophic eastern basin scattered between 1 and $8 \mu \mathrm{g}^{-1} \mathrm{Chl} a$, with, again, repetitive spikes on top across years (Fig. 2C, D). These summer peaks, especially at the end of the study period, were less apparent as compared to those from the western basin (Fig. 2A). Nevertheless, both the annual maxima (Fig. 2C, red dashed line) and averaged values (Fig. 2D, solid lines) showed the same declining trend as was observed in the western basin (see Fig. 2A and B). However, in the eastern basin, the corresponding values were much lower, each by a factor of approximately three (note that the scales differ on the vertical axis.). In this basin, the annual mean $\mathrm{Chl} a$ concentration decreased below $3 \mu \mathrm{g}^{-1}$ in years 2015 and 2017. Unsurprisingly, the Chl $a$ data obtained from the

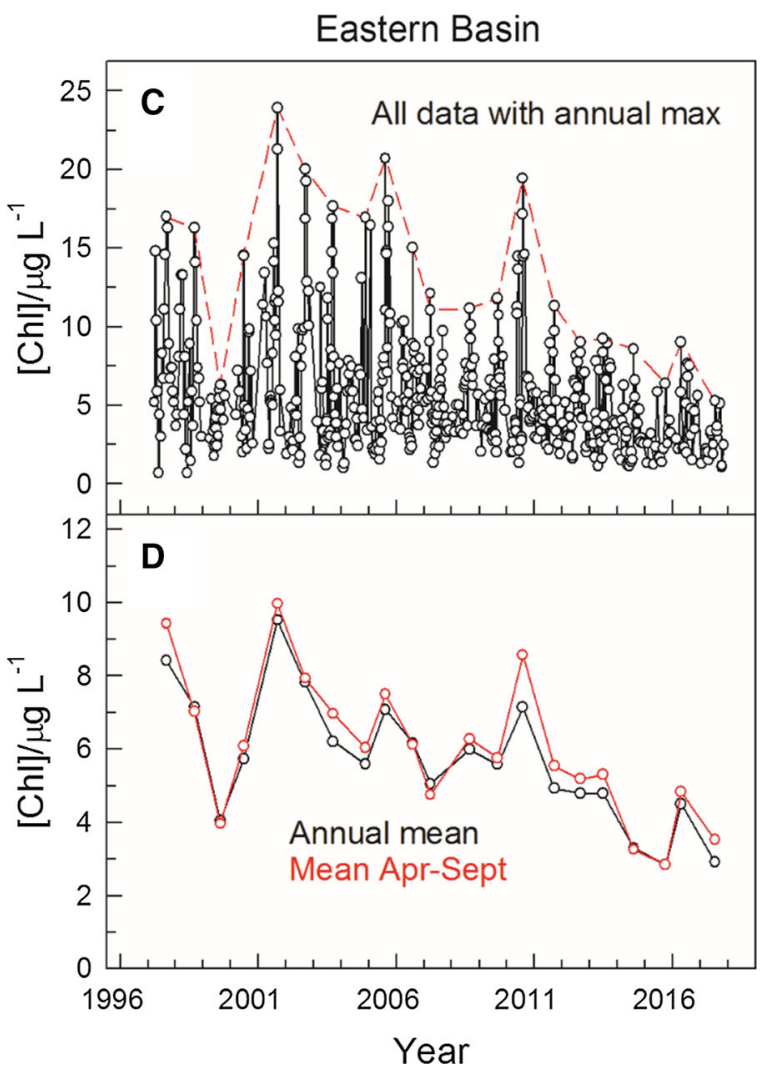

C show all data obtained with a contour line of annual maxima (red dashed line), panels $\mathbf{C}$ and $\mathbf{D}$ show annual means (black) as well as means over the annual April to September periods (red) 
middle basin area similarly showed a declining trend, with values falling between those of the western and eastern basins (data not shown).

The statistical analysis corroborated the monotonous decline in Chl $a$ concentration with time, and the trophic gradient along the longitudinal axis of Lake Balaton was also evident $\left(R^{2}=0.768\right.$; regression coefficients and their $P$-values: intercept (20.436, $\left.P<2 \times 10^{-16}\right)$, years $\left(-0.500, p=5.30 \times 10^{-8}\right)$, middle basin $\left(-5.749, p=1.49 \times 10^{-7}\right)$, eastern basin $\left.\left(-10.101, p=1.52 \times 10^{-14}\right)\right)$. Hence, the calculated regression equation for $\mathrm{Chl} a$ concentration is: yearly mean $\mathrm{Chl} a \quad\left(\mu \mathrm{g} \mathrm{l}^{-1}\right)=-$ $20.436-0.50 \times$ year (from 1 to 17$)+$ basin_effect, where basin_effect is $0,-5.749$ and -10.101 for the western, middle and eastern basin, respectively. Thus, the Chl $a$ concentration in Lake Balaton declined with an average of $0.5 \mathrm{~g} \mathrm{I}^{-1}$ yearly during the study period.

In contrast to the similarities in long-term changes in Chl $a$ concentration (and phytoplankton biomass, data not shown) in all three basins during oligotrophication, the corresponding changes in zooplankton biomass showed a different pattern in each basin. Although the zooplankton biomass data from the western basin exhibited much higher scattering as compared to the corresponding phytoplankton ( $\mathrm{Chl} a$ ) data, they showed the same overall decreasing trend (Fig. 3A, B). In addition, while the majority of individual zooplankton biomass data fell between 150 and $800 \mu \mathrm{g}^{-1}$, they also showed repetitive spikes (up to $2,900 \mu \mathrm{g}^{-1}$; highlighted by red dashed line), which, similar to phytoplankton peaks, occured mostly in late summer. Likewise, maximal and annual mean of individual zooplankton densities, expressed as ind $1^{-1}$, showed the same trends (data not shown). These all indicated, expectedly, a tight correlation between the phytoplankton and zooplankton biomass and bottom-up control of the latter. Neither the annual maxima of the zooplankton biomass (red dashed line) nor its yearly mean levels showed a clear tendency in the eastern basin (Fig. 3C and D, respectively). The zooplankton biomass levels in the middle basin fall again between those of the western and eastern basins, i.e. showed only a moderate decrease during the past two decades (data not shown).

Similar to Chl a concentration, the statistical analysis of zooplankton biomass data clearly showed a long-term decrease, as well as a concomitant increase along the longitudinal axis of the lake (regression model: $R^{2}=0.325$; coefficients and their $P$-values: intercept $\left(6.476, P<2 \times 10^{-16}\right)$, years $(-0.028, \quad P=0.002), \quad$ middle basin $(-0.368$, $P=0.001)$, eastern basin $(-0.348, P=0.002))$. The corresponding regression equation for zooplankton biomass was: log (yearly mean zooplankton biomass $\left.\left(\mu \mathrm{g}^{-1}\right)\right)=6.476-0.03 \times$ year $($ from 1 to 17$)$ + basin_effect, where basin_effect is $0,-0.368$ and -0.348 for the western, middle and eastern basin, respectively. This is equivalent to a $3.6 \%$ yearly mean decrease in zooplankton biomass during the study period.

To visualize long-term changes, we calculated multiannual mean values, covering 4-5 years, for each basin. The resulting long-term trends in $\mathrm{Chl}$ $a$ concentration and zooplankton biomass are shown in Fig. 4A and B, respectively.

Interrelationship between Chl $a$ concentration and zooplankton biomass

We investigated the response of zooplankton to changes in phytoplankton biomass (i.e. Chl $a$ ). Statistical analysis revealed that $\mathrm{Chl} a$ concentration had a significant effect on zooplankton biomass ( $\mathrm{df}=1 / 45$; $F=12.99 ; P<0.001$ ), when the basin- and year effects were considered in our model.

There was a nonlinear response of zooplankton biomass to changes in Chl a concentration, as highlighted in Fig. 5. The relationship between zooplankton biomass and $\mathrm{Chl} a$ concentration was steep and positive above approximately $10 \mu \mathrm{g} \mathrm{l}^{-1} \mathrm{Chl}$ $a$ concentration (Fig. 5A). However, below this threshold the relationship was weaker, i.e., the zooplankton biomass is apparently higher than expected based on a linear extrapolation of data obtained with higher Chl $a$ concentrations. This result was much more evident when $\mathrm{Chl} a$ concentration and zooplankton biomass data are plotted on a double logarithmic scale (Fig. 5B). Nevertheless, in spite of this atypical relationship, the zooplankton to $\mathrm{Chl}$ $a$ concentration $(\mathrm{Z} / \mathrm{Chl})$ as well as zooplankton to phytoplankton $(Z / P)$ ratios followed a general pattern, i.e. increased considerably with decreasing $\mathrm{Chl} a$ concentration and phytoplankton biomass (Fig. 6A-C; see also "Introduction" section). Interestingly, neither the $Z / C h l$ nor the $Z / P$ ratio change much above $10 \mu \mathrm{g} \mathrm{l}^{-1} \mathrm{Chl} a$ (Fig. 6A, C) in agreement with the 
Western Basin

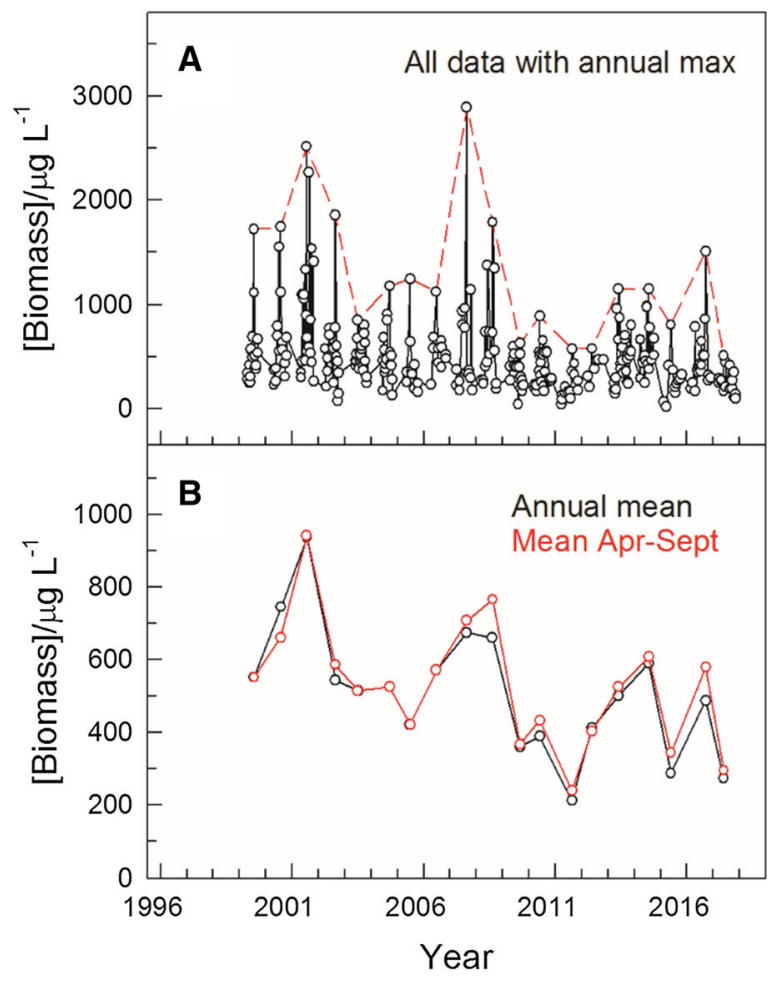

Fig. 3 Changes in zooplankton dry weight biomass in the western $(\mathbf{A}, \mathbf{B})$ and eastern basin $(\mathbf{C}, \mathbf{D})$ of Lake Balaton from 1997 to 2017. While panels A and C show all data obtained with

linear relationship between zooplankton biomass and Chl $a$ concentration in this trophic range (Fig. 5), while below that threshold the double-logarithmic plot (Fig. 6B) shows a linear decrease, which is characteristic for meso-eutrophic systems (Yuan \& Pollard, 2018). With decreasing Chl $a$ concentration and phytoplankton biomass, the calculated $Z / P$ ratios increased from about $0.5-0.6$ to about 2.6-2.7 (Fig. 6C, D).

Changes in the phytoplankton size distribution during oligotrophication

Comparing the relative contribution of edible $(<25 \mu \mathrm{m}$ in size $)$ and non-edible $(>25 \mu \mathrm{m})$ phytoplankton as a function of total phytoplankton biomass, a tenfold decrease in the annual mean phytoplankton biomass is accompanied by a substantial increase in the relative contribution of the small, edible phytoplankton (from about $30 \%$ to about $70 \%$ ), while the corresponding contribution of non-edible fraction

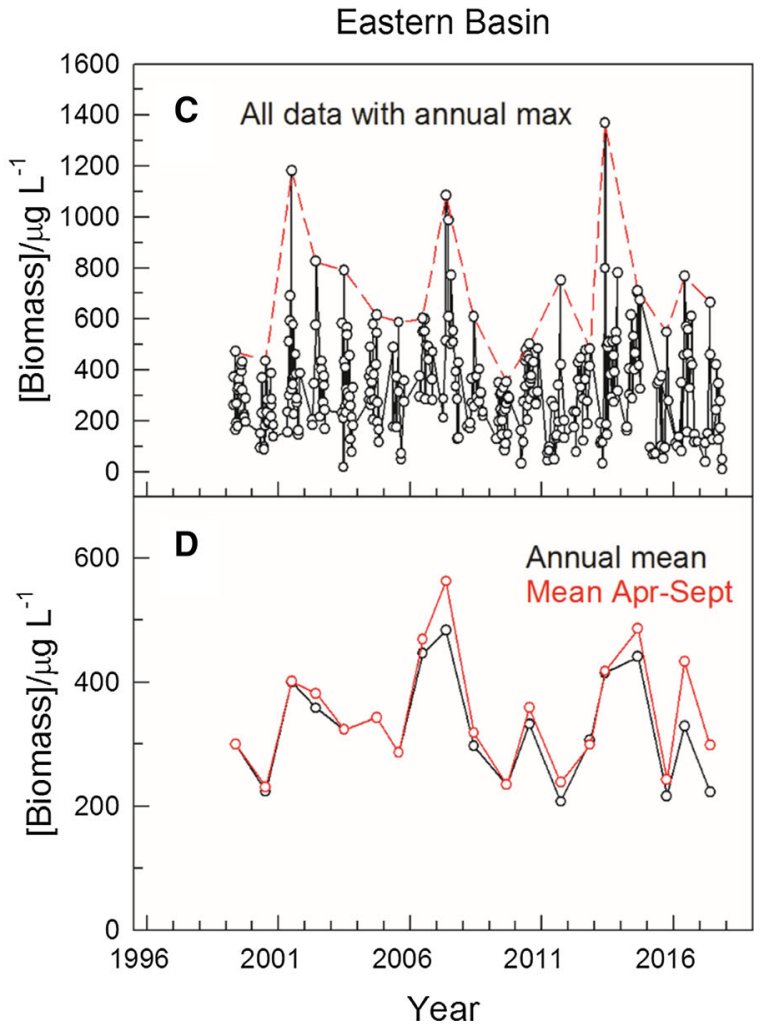

a contour line of annual maxima (red dashed line), panels $\mathbf{C}$ and D show annual means (black) as well as means over the annual April to September periods (red)

changed in the opposite direction (Fig. 7A and B, respectively). Furthermore, the annual mean zooplankton biomass was independent of the total (annual) biomass of non-edible phytoplankton (Fig. 8A, B), while the biomass of edible phytoplankton clearly showed a linear relationship (Fig. 8C, D; $R^{2}=0.35$ ).

\section{Discussion}

Our data on zooplankton biomasses and Chl $a$ concentrations and ratios concur with global trends but also show some lake-specific differences. As expected, reoligotrophication of Lake Balaton has been accompanied by a significant decrease in Chl $a$ concentration (hence, in phytoplankton biomass) in both space (across the west-east trophic gradient) and time (across year-groups) regardless of the trophic state. The maximal annual values during the study period (25-65 $\mu \mathrm{g} \mathrm{l}^{-1} \mathrm{Chl} a$ in the western basin) were much 

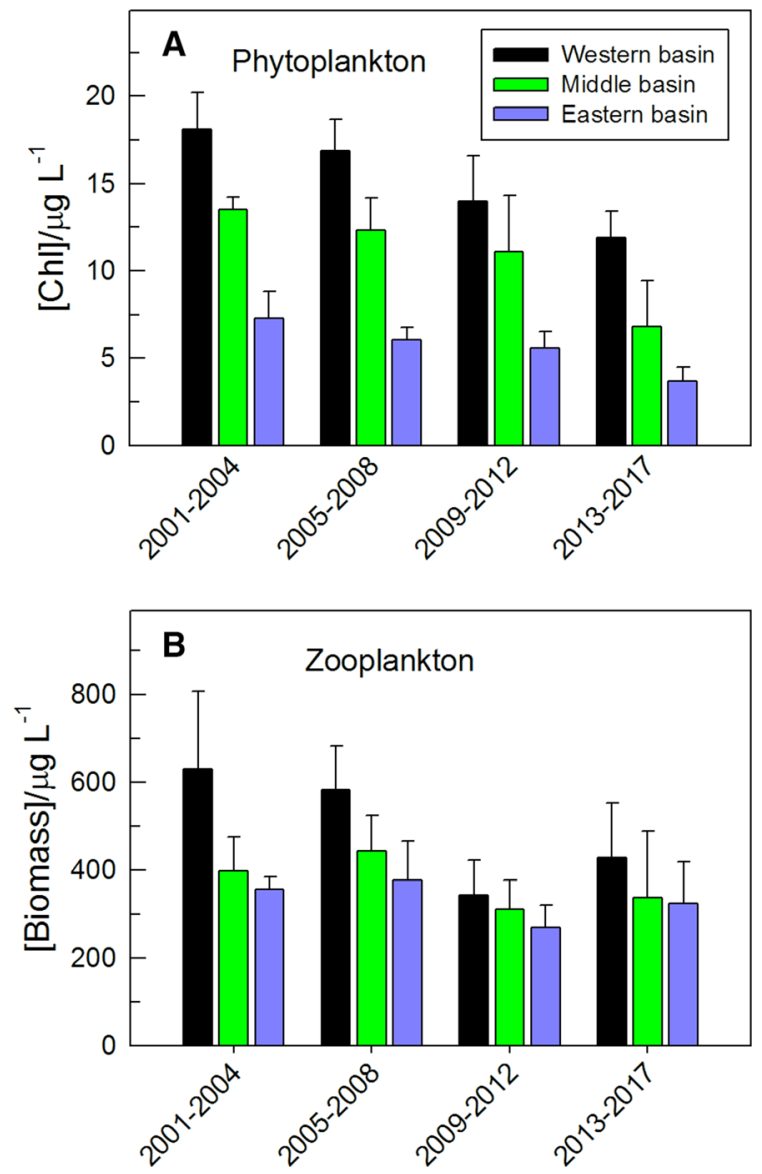

Fig. 4 Long-term changes in multiannual mean chlorophyll $a$ concentration (A) and zooplankton dry weight biomass (B) in the western- (black), middle- (green), and eastern basin (blue) of Lake Balaton from 2001 to 2017. Averages of $4-5$ years is considered with standard deviation indicated as error bars

below the mean peak concentrations (up to $125 \mu \mathrm{g} \mathrm{l^{-1 }}$ Chl $a$ ) recorded in 1986 and early 1990s (Specziár \& Vörös, 2001). A concomitant increase in the $Z / C h l$ ratios during oligotrophication also occurred. However, there was an atypical nonlinear response of zooplankton biomass to $\mathrm{Chl} a$ concentration, i.e. a steep decrease in the multiannual mean zooplankton biomass level with decreasing Chl $a$ level only above a certain concentration ( $>10 \mu \mathrm{g} \mathrm{l^{-1 }} \mathrm{Chl} a$; Figs. 3,4B, and 5). Below this threshold the relationship between zooplankton biomass and $\mathrm{Chl} a$ concentration was much weaker due to relatively high zooplankton biomasses (Fig. 5). This pattern, with (i) relatively high zooplankton biomass at higher trophic states and (ii) relatively stable zooplankton biomass below a certain Chl $a$ concentration, differs remarkably from
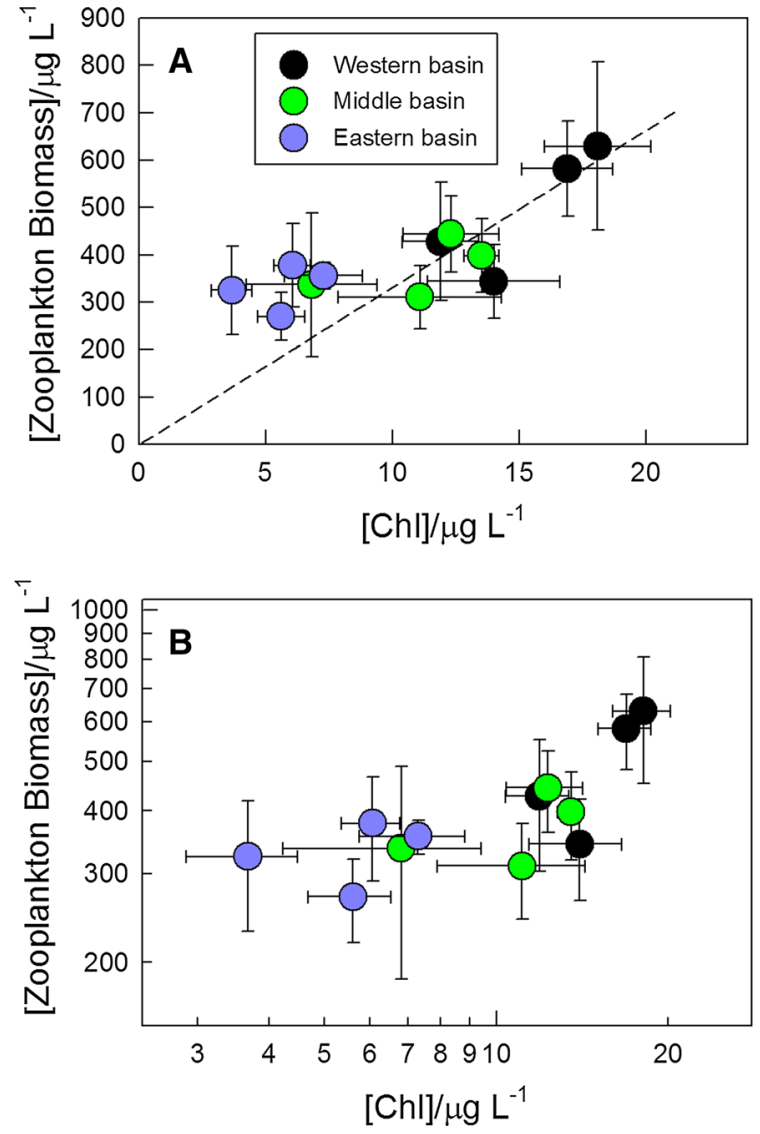

Fig. 5 Relationship between multiannual mean chlorophyll $a$ concentration and zooplankton dry weight biomass plotted on linear- (A) and on double-logarithmic (B) axes. Data are taken from Fig. 4 with error bars shown. Dashed line on panel A shows the linear fit of data obtained from the middle and eastern basin only assuming a zero intercept. Color coding is the same as of Fig. 4

previously published data on the interrelationship between phyto- and zooplankton biomass, which followed either a linear or power function or showed linearity only at very low phytoplankton biomasses (i.e. in oligotrophic lakes) rather than at high(er) ones (McCauley \& Kalff, 1981; Hart, 2011; Yuan \& Pollard, 2018). Even among the cases which were best fit with power functions there was only one with an exponent $>1$ (i.e. increasing zooplankton biomass with increasing phytoplankton biomass) but that case showed a quasi-linear dependence of the zooplankton biomass on the phytoplankton level $(N=1.15$; Hart, 2011). We attempt to explain this trend to a substantial enrichment in food quality parallel to oligotrophication, i.e. much higher percentage of phytoplankton 

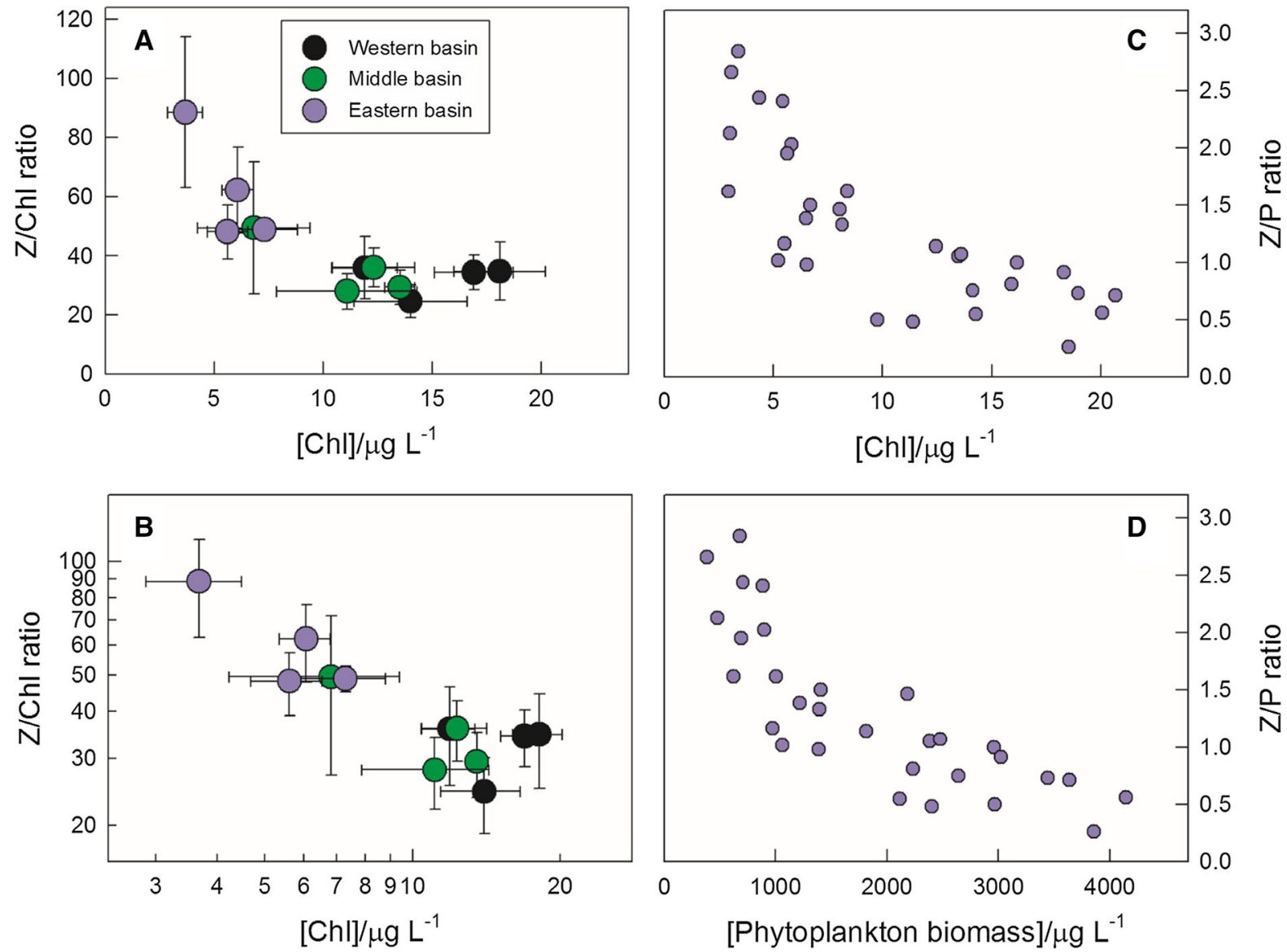

Fig. 6 Relationship between the trophic state (multiannual mean chlorophyll $a$ concentration, phytoplankton dry biomass) and the ratio of zooplankton dry weight biomass to chlorophyll $a$ concentration $(Z / \mathrm{Chl} ; \mathbf{A}, \mathbf{B})$ and to phytoplankton biomass (Z/ $P$; C, D). Z/Chl data are plotted on both standard linear- (A) and

community falls in the size range of smaller than $2 \mu \mathrm{m}$ (Fig. 7) which could be considered as the size limit, in regards of edibility, for various zooplankton taxa (Levine et al., 1999; c.f. Bell, 2002; Agasild et al., 2007). This change in phytoplankton composition and the linear relationship between the biomass of edible phytoplankton and zooplankton biomass (Fig. 8C, D) concurs with the earlier observations (McCauley \& Kalff, 1981; Hart, 2011; Heathcote et al., 2016). In addition, parallel to the (relative) increase in the edible phytoplankton fraction with decreasing total phytoplankton biomass, the relative contribution of unicellular cyanobacteria with poor nutritional value (de Bernardi \& Giussani, 1990) also decreases, which may also contribute to the relatively high zooplankton biomass at low phytoplankton levels. The increase in

on double-logarithmic (B) axes; data in these panels are taken from Fig. 5 with error bars shown with color coding is the same as of Figs. 4 and 5. Dry weight phytoplankton biomass was assumed to be $20 \%$ of the corresponding wet weight biomass (C, D)

the edible phytoplankton fraction is expected to also be related to an increase in the Cladocera/Copepoda abundance ratios (Sommer \& Sommer, 2006).

The calculated $Z / C h$ ratios in Lake Balaton also follow the global pattern, i.e., a decrease with increasing phytoplankton biomass density and trophic state and vice versa, increasing substantially with oligotrophication (Fig. 6). Although Chl $a$ content of the phytoplankton biomass is season-, species- and also light dependent, based on Z/Chl values, a rough estimation on the zooplankton-to-phytoplankton (Z/ $P$ ) biomass ratios was also calculated (see "Methods" section). This resulted in a $Z / P$ ratio of about 0.68 to 2.42 , in very good agreement with the $Z / P$ data obtained by direct bio-volume determination. These values are much higher than most of the corresponding 

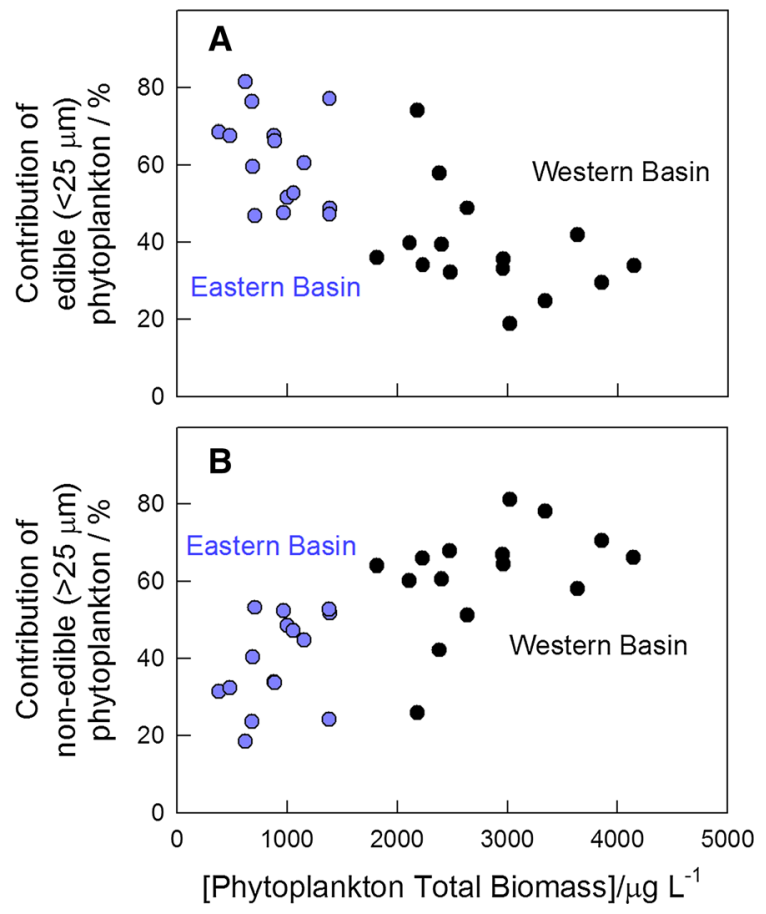

Fig. 7 Relative contribution of edible $(<25 \mu \mathrm{m}$, (A) and nonedible $(>25 \mu \mathrm{m},(\mathbf{B})$ phytoplankton as a function of total phytoplankton biomass. All data points represent annual mean values. Data from the western and eastern basin are marked by black and blue dots, respectively

values in other shallow lakes with meso-eutrophic character (Jeppesen et al., 2003). Remarkably, at the end of the study period, the multiannual mean zooplankton biomass exceeded more than twofold the corresponding phytoplankton biomass in the oligotrophic eastern basin. Such an inverted biomass pyramid is characteristic for systems with low standing stock of primary producers with high production rates, and these criteria are often met in lakes with low phytoplankton biomass (del Giorgo \& Gasol, 1995). The observed high $Z / P$ ratios also mean that the turbid character of the lake, which is detrimental for largesized zooplankters, does not have an overall negative impact on the zooplankton biomass in Lake Balaton. Moreover, the role of benthic or other sources (e.g. microbial loop) cannot be excluded; addressing these questions needs further investigations, such as stable isotope studies.

Although the relationship between fish- and zooplankton biomass has to be considered carefully in shallow lakes, where a substantial fraction of biomass (i.e. of invertebrates as fish food) is produced in the benthic and littoral zone, shifts in zooplankton biomass is expected to cause changes in the fish assemblage and biomass. Indeed, the eutrophication of Lake Balaton from the 1960s to 1990s was accompanied by a substantial increase in fish biomass (Bíró, 1997; Tátrai et al., 2008), while the onset of oligotrophication induced extensive fish kills in 1995 (Bíró, 1997). However, the subsequent water quality improvement of Lake Balaton over the study period between 2001 and 2017 was not accompanied by any (further) decrease in catch per unit effort (CPUE) values for the three dominant planktivorous fishes in Lake Balaton: common bream (Abramis brama L.), common bleak (Alburnus alburnus L.), and razor fish (Pelecus cultratus L.) (Specziár, 2010; Specziár \& Erös, 2020). This observation is in accordance with the data available in the National Fishery Database (Hungary) on annual fishery yields in Lake Balaton between 2003 and $2013\left(676.6 \pm 137.1 \mathrm{t} \mathrm{year}^{-1}\right)$, which show no decreasing trend in CPUE during this period (fishery data is available until 2013). However, the stable or even increasing fish biomass along with decreasing phytoplankton level is in contrast with most of the available literature data, reporting decreasing fish biomass with decreasing phytoplankton biomass density and/or increasing $Z / P$ ratios (Bíró \& Vörös, 1982; Jeppesen et al., 1997, 2003; Tátrai et al., 2008). This result requires further investigation. Nevertheless, only a minor part of the variances in gut content (i.e. diet) and within-lake distribution pattern of the above mentioned fish species could be explained by spatial factors, and longitudinal environmental gradient has significant effect only at the habitat level (Specziár et al., 2013; Specziár \& Erős, 2014). The observed high $Z / P$ ratios and relatively high zooplankton biomass densities below $10 \mu \mathrm{g} \mathrm{l}^{-1} \mathrm{Chl} a$ concentration may provide a partial explanation for these phenomena.

Ecosystem services provided by lakes, especially in densely populated and/or areas attractive as tourist destinations such as the Balaton-region, must fulfil complex, often antagonistic societal requirements, including regulating- (i.e. water regulation), supply(drinking water, fishing and/or angling), conservation(nature protection, ecosystem complexity) and cultural functions (recreation, sport, tourism) (Fulop, 2016). Changes in the water quality affect most of these functions, to various extents. Eutrophication, due to the accompanying deterioration of water quality 
Non-edible, $>25 \mu \mathrm{m}$

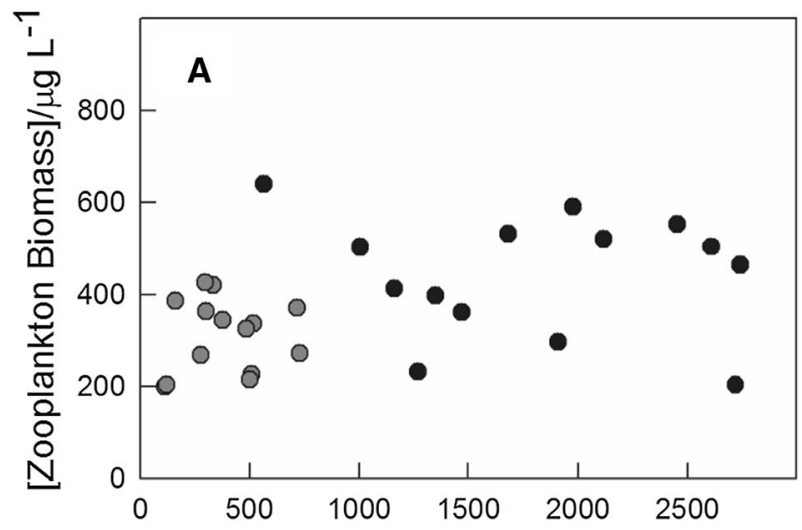

[Phytoplankton Biomass]/ $\mu \mathrm{g} \mathrm{L}^{-1}$

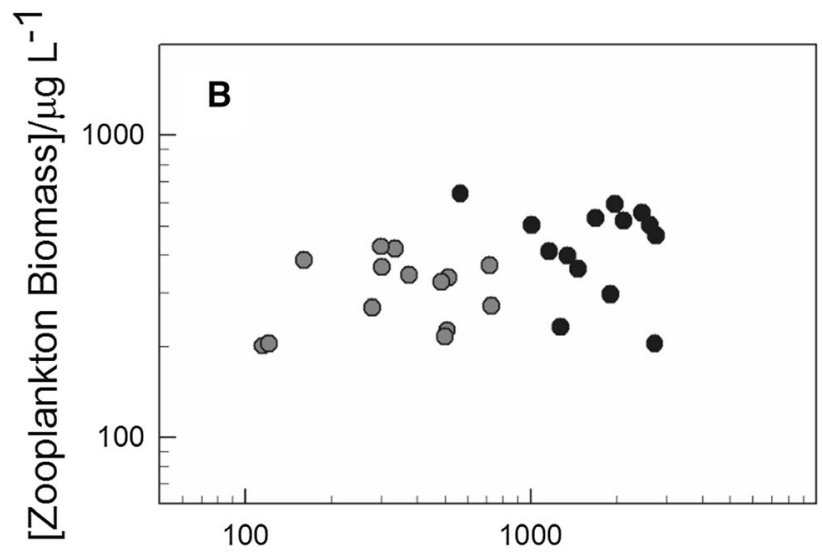

[Phytoplankton Biomass] $/ \mu \mathrm{g} \mathrm{L}{ }^{-1}$

Fig. 8 Relationship between the biomass of non-edible $(>25$ $\mu \mathrm{m}, \mathbf{A}, \mathbf{B})$ and edible $(<25 \mu \mathrm{m}, \mathbf{C}, \mathbf{D})$ phytoplankton and zooplankton plotted on standard linear- $(\mathbf{A}, \mathbf{C})$ and on doublelogarithmic (B, D) axes. Data on panels $\mathbf{C}$ and $\mathbf{D}$ are fitted with a

and related potential health risks, is generally considered to be negative in terms of cultural functions. In turn, oligotrophication is generally considered to be positive owing to improvements in water quality. On the other hand, the impact of eutrophication on fishery and angling (i.e. on fish biomass) is expected to be positive, despite the relative decrease in zooplankton biomass as compared to phytoplankton biomass. Oligotrophication might have a negative impact on fish productivity, and therefore, on fishery yields. However, fish catch data have shown no substantial decrease in the more recent phase of the ongoing oligotrophication (see above), possibly, at least to a certain extent, due to the relatively high zooplankton

Edible, $<25 \mu \mathrm{m}$

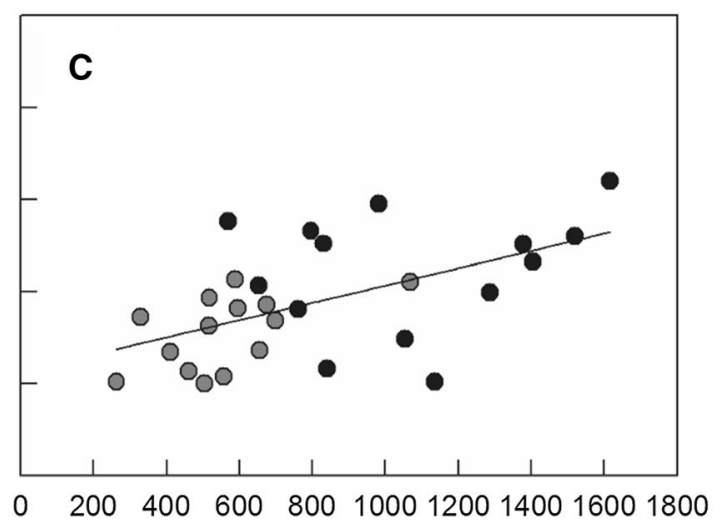

[Phytoplankton Biomass] $/ \mu \mathrm{g} \mathrm{L}^{-1}$

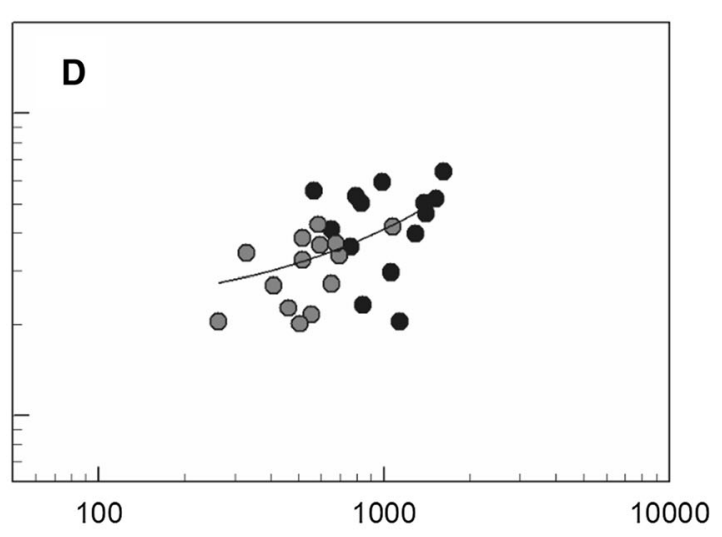

[Phytoplankton Biomass] $/ \mu \mathrm{g} \mathrm{L}{ }^{-1}$

linear function. All data points represent annual mean values. Data from the western and eastern basin are marked by black and blue dots, respectively

abundance even at low phytoplankton densities and adaptive responses of zooplanktivorous fish to changing trophic state. Moreover, most of the preferred game fishes feed primarily on benthic and periphytic food resources, and therefore, they are less affected by variations in zooplankton production (Specziár \& Rezsu, 2009; Specziár, 2010). Thus, oligotrophication and improved water quality of Lake Balaton could be considered as a story of success in regards of providing various ecosystem services, including good water quality without a considerable decline in fish stock. 


\section{Conclusions}

During the re-oligotrophication of Lake Balaton, we found a proportional decrease of zooplankton and phytoplankton biomass at moderate phytoplankton levels. However, below a certain phytoplankton concentration, the decrease in phytoplankton biomass did not involve a further decline in zooplankton biomass as the fraction of small phytoplankton, edible for zooplankton, showed a much smaller decrease in biomass than that of the large, non-edible one. Thus, different from the overall global trend, water quality improvement (i.e. a decrease in nutrient input level) and accompanying increases in the zooplankton-tophytoplankton biomass ratio did not induce a decrease in the fish stock of Lake Balaton, which is well supported by the CPUE data obtained by gill net fishing.

Acknowledgements We are grateful to Géza Dobos for his help in sample collection, and to Balázs Németh, Nóra SzabóTugyi, and Beáta Maroskövi for their technical assistance. This work was supported by the Hungarian Academic Foundation (OTKA) [grant no. PD112449 to B. Somogyi, and K128950 to G. Bernát and B. Somogyi] and GINOP [grant no. GINOP2.3.2-15-2016-00004 to G. Bernát, G. Boros, and N. Boross]. We thank Andrew Hamer and András Specziár as well as the two anonymous reviewers for their careful reading of the manuscript and helpful comments and suggestions, and for Laura Parpala for her long-standing enthusiasm and expertise in analyzing zooplankton dynamics. G. Boros was supported by the János Bolyai Research Fellowship from the Hungarian Academy of Sciences.

Funding Open access funding provided by ELKH Centre for Ecological Research.

Open Access This article is licensed under a Creative Commons Attribution 4.0 International License, which permits use, sharing, adaptation, distribution and reproduction in any medium or format, as long as you give appropriate credit to the original author(s) and the source, provide a link to the Creative Commons licence, and indicate if changes were made. The images or other third party material in this article are included in the article's Creative Commons licence, unless indicated otherwise in a credit line to the material. If material is not included in the article's Creative Commons licence and your intended use is not permitted by statutory regulation or exceeds the permitted use, you will need to obtain permission directly from the copyright holder. To view a copy of this licence, visit http://creativecommons.org/licenses/by/4.0/.

\section{References}

Agasild, H., P. Zingel, I. Tõnno, J. Haberman \& T. Nõges, 2007. Contribution of different zooplankton groups in grazing on phytoplankton in shallow eutrophic Lake Võrtsjärv (Estonia). Hydrobiologia 584: 167-177.

Bell, T., 2002. The ecological consequences of unpalatable prey: phytoplankton response to nutrient and predator additions. Oikos 99: 59-68.

Benndorf, J., W. Böing, J. Koop \& I. Neubauer, 2002. Top-down control of phztoplnkton: the role of time scale, lake depth and trophic state. Freshwater Biology 47: 2282-2295.

Bíró, P., 1997. Temporal variation in Lake Balaton and its fish populations. Ecology of Freshwater Fish 6: 196-216.

Biró, P. \& L. Vörös, 1982. Relationships between phytoplankton and fish yields in Lake Balaton. Hydrobiologia 97: 3-7.

Bolgovics, Á., É. Ács, G. Várbíró, J. Görgényi, K. T. Kiss, A. Földi, Z. Nagy-László, Z. Trábert \& G. Borics, 2017. Benthic diatom-based lake types in Hungary. Fundamental and Applied Limnology 189: 105-116.

Danielsdottir, M. G., M. T. Brett \& G. B. Arhonditis, 2007. Phytoplankton food quality control of planktonic food web processes. Hydrobiologia 589: 29-41.

de Bernardi, R. \& G. Giussani, 1990. Are blue-green algae a suitable food for zooplankton? An overview. Hydrobiologia 200: 29-41.

del Giorgo, P. A. \& J. M. Gasol, 1995. Biomass distribution in freshwater plankton communities. American Naturalist 146: 135-152.

Dokulil, M. T., A. Herzig, B. Somogyi, L. Vörös, K. Donabaum, L. May \& T. Nöges, 2014. Winter conditions in six European shallow lakes: A comparative synopsis. Estonian Journal of Ecology 63: 111-129.

Dumont, H. J., I. Van de Velde \& S. Dumont, 1975. The dry weight estimate of biomass in a selection of Cladocera, Copepoda and Rotifera from the plankton, periphyton and benthos of continental waters. Oecologia (Berl.) 19: 75-97.

Felföldi, T., M. Duleba, B. Somogyi, B. Vajna, M. Nikolausz, M. Présing, K. Márialigeti \& L. Vörös, 2011. Diversity and seasonal dynamics of the photoautotrophic picoplankton in Lake Balaton (Hungary). Aquatic Microbial Ecology 63: 273-287.

Fox, J. \& S. Weisberg, 2011. An R Companion to Applied Regression, 2nd ed. SAGE Publications, Thousand Oaks.

Fulop, S., 2016. Wilderness protection in Hungary. In Bastmeijer, K. (ed.), Wilderness Protection in Europe. R = The Role on International, European and National Law. Cambridge University Press, Cambridge.

G.-Tóth, L., 1992. Limiting effect of abioseston on food ingestion, postembryonic development time and fecundity of daphnids in Lake Balaton (Hungary). Journal of Plankton Research 14: 435-446.

G.-Tóth, L., N. P. Zánkai \& O. M. Messner, 1987. Alga consumption of four dominant planktonic crustaceans in Lake Balaton (Hungary). Hydrobiologia 145: 323-332.

G.-Tóth, L., P. Parpala, C. Balogh, I. Tátrai \& E. Baranyai, 2011. Zooplankton community response to enhanced turbulence generated by water-level decrease in Lake Balaton, the largest shallow lake in central Europe. Limnology Oceanography 56: 2211-2222. 
Gsell, A. S., D. Özkundakci, M.-P. Hébert \& R. Adrian, 2015. Quantifying change in pelagic plankton network stability and topology based on empirical long-term data. Ecological Indicators 65: 76-88.

Hajnal, É. \& J. Padisák, 2007. Analysis of long-term ecological status of Lake Balaton based on the ALMOBAL phytoplankton database. Hydrobiologia 599: 227-237.

Hart, R. C., 2011. Zooplankton biomass to chlorophyll ratios in relation to trophic status and between ten South African reservoirs: casual inferences, and implications for biomanipulation. Water SA 37: 513-522.

Heathcote, A. J., C. T. Filstrup, D. Kendall \& J. A. Downing, 2016. Biomass pyramids in lake plankton: influence of Cyanobacteria size and abundance. Inlands Waters 6: 250-257.

Herodek, S., 1986. Phytoplankton changes during eutrophication and $\mathrm{P}$ and $\mathrm{N}$ metabolism. In Somlyódi, L. \& G. Van Straten (eds), Modeling and Managing Shallow Lake Eutrophication. Springer, Berlin: 183-203.

Ho, J. C., A. M. Michalak \& N. Pahlevan, 2019. Widespread global increase in intense lake phytoplankton blooms since 1980s. Nature 574: 667-670.

Istvánovics, V., A. Clement, L. Somlyódi, A. Specziár, L. G.Tóth \& J. Padisák, 2007. Updating water quality targets for shallow Lake Balaton (Hungary), recovering from eutrophication. Hydrobiologia 581: 305-318.

Jeppesen, E., J. P. Jensen, M. Søndergaard, T. Lauridsen, L. J. Pedersen \& L. Jensen, 1997. Top-down control in freshwater lakes: the role of nutrient state, submerged macrophytes and water depth. Hydrobiologia 342(343): 151-164.

Jeppesen, E., J. P. Jensen, C. Jensen, B. Faafeng, D. O. Hessen, M. Søndergaard, T. Lauridsen, P. Brettum \& K. Christoffersen, 2003. The impact of nutrient state and lake depth on top-down control in the pelagic zone of lakes: a study of 466 lakes from the temperate zone to arctic. Ecosystems 6 : 313-325.

Jeppesen, E., M. Søndergaard, J. P. Jensen, K. E. Havens, O. Anneville, L. Carvalho, M. F. Coveney, R. Deneke, M. T. Dokulil, B. Foy, D. Gerdeaux, S. E. Hampton, S. Hilt, K. Kangur, J. Köhler, E. H. H. R. Lammens, T. L. Lauridsen, M. Manca, M. R. Miracle, B. Moss, P. Nõges, G. Persson, G. Phillips, R. Portielje, S. Romo, C. L. Schelske, D. Straile, I. Tatrai, E. Willén \& M. Winder, 2005. Lake responses to reduced nutrient loading: an analysis of contemporary long-term data from 35 case studies. Freshwater Biology 50: 1747-1771.

Karjalainen, J., A.-L. Holopainen \& P. Huttunen, 1996. Spatial patterns and relationship between phytoplankton, zooplankton and water quality in the Saimaa lake system, Finland. Hydrobiologia 322: 267-276.

Kasprzak, P., J. Padisák, R. Koschel, L. Krientitz \& F. Gervais, 2006. Chlorophyll $a$ concentration across a trophic gradient of lakes: an estimator of phytoplankton biomass? Limnologica 38: 327-338.

Levine, S. N., M. A. Borchardt, M. Branaer \& A. D. Shambaugh, 1999. The impact of zooplankton grazing on phytoplankton species composition and biomass in Lake Champlain (USA-Canada). Journal of Great Lakes Research 25: 61-77.
Lund, J. W. G., C. Kipling \& E. D. Lecren, 1958. The inverted microscope method of estimating algal numbers and the statistical basis of estimations by counting. Hydrobiologia 11: $143-170$.

MacIsaac, E. A. \& J. G. Stockner, 1993. Enumeration of phototrophic picoplankton by autofluorescence microscopy. In Kemp, P. F., B. F. Sherr, E. B. Sherr \& J. J. Cole (eds), Handbook of Methods in Aquatic Microbial Ecology. Lewis Publishers, Boca Raton: 187-197.

McCauley, E. \& J. Kalff, 1981. Empirical relationship between phytoplankton and zooplankton biomass in lakes. Canadian Journal of Fisheries and Aquatic Sciences 38: 458-463.

Mooij, W. M., J. H. Janse, L. N. De Senerpont Domis, S. Hülsmann \& B. W. Ibelings, 2007. Predicting the effect of climate change on temperate shallow lakes with the ecosystem model PCLake. Hydrobiologia 584: 443-454.

Ngatia, L. \& R. Taylor. 2018. Phosphorous eutrophication and mitigation strategies. In: Zhang, T. (ed.), Phosphorus. Recovery and recycling. IntechOpen. https://doi.org/10. 5772/intechopen.79173

Nõges, P., U. Mischke, R. Laugaste \& A. G. Solimini, 2010. Analysis of changes over 44 years in the phytoplankton of Lake Võrtsjärv (Estonia): the effect of nutrients, climate and the investigator on phytoplankton-based water quality indices. Hydrobiologia 646: 33-48.

Odermatt, J. M., 1970. Limnologische Charakterisierung des Lauerzersees mit besonderer Berücksichtigung des Planktons. Schweizerische Zeitschrift für Hydrologie 32: 1-75. (in German).

Padisák, J., \& R. Adrian. 1999. Chapter 5.1., Biovolumen und Biomasse. In: W. V. Tümpling, G. Friedrich (eds), Biologische Gewässerunguntersuchung. Gustav Fischer Verlag Jena

Peters, F. \& C. Marrasé, 2000. Effects of turbulence on plankton: an overview of experimental evidences and theoretical considerations. Marine Ecology Progress Series 205: 291-306.

Ponyi, J. \& N. P. Zánkai, 1982. Population dinamics, biomass, and biomass production of Eudiaptomus gracilis (G. O. SARS) in two water areas of different trophic state of Lake Balaton (Hungary). Acta Hydrochimica et Hydrobiologica 10: 597-610.

R Core Team. 2016. R: a language and environment for statistical computing. Vienna: R Foundation for Statistical Computing (software)

Schindler, D. W., 2006. Recent advances in the understanding and management of eutrophication. Limnology and Oceanography 51: 356-363.

Sommer, U. \& F. Sommer, 2006. Cladocerans versus copepods: the cause of contrasting top: down controls on freshwater and marine phytoplankton. Oecologia 147: 183-194.

Specziár, A., 2010. A Balaton halfaunája: a halállomány összetétele, az egyes halfajok életkörülményei és a halállomány korszerű hasznosításának feltételrendszere. Acta Biologica Debrenica Supplementum Oecologica Hungarica 23: 7-185. (in Hungarian).

Specziár, A. \& T. Erös, 2014. Dietary variability in fishes: the roles of taxonomix, spatial, temporal and ontogenetic factors. Hydrobiologia 724: 10-125. 
Specziár, A., \& T. Erős. 2020. Development of a fish-based index for the assessment of the ecological status of Lake Balaton in the absence of present day reference condition. Knowledge and Management of Aquatic Ecosystems 421: Article No. 11.

Specziár, A. \& E. T. Rezsu, 2009. Feeding guilds and food resource partitioning in a lake fish assemblage: an ontogenetic approach. Journal of Fish Biology 75: 247-267.

Specziár, A. \& L. Vörös, 2001. Long-term dynamics of Lake Balaton's chironomid fauna and its dependence on the phytoplankton production. Archiv fur Hydrobiologie 152: 119-142.

Specziár, A., Á. I. György \& T. Erős, 2013. Within-lake distribution patterns of fish assemblages: the relative roles of spatial, temporal and random environmental factors in assessing fish assemblages using gillnets in a large and shallow temperate lake. Journal of Fish Biology 82: 840-855.

Szabó-Tugyi, N., L. Vörös, K. V.-Balogh, Z. Botta-Dukát, G. Bernát, D. Schmera \& B. Somogyi, 2019. Aerobic anoxygenic phototrophs are highly abundant in hypertrophic and polyhumic waters. FEMS Microbiology Ecology 95: 104.

Tátrai, I., V. Istvánovics, L. G-Tóth \& I. Kóbor, 2008. Management measures and long-term water quality changes in Lake Balaton (Hungary). Fundamental and Applied Limnology 172: 1-11.
Utermöhl, H., 1958. Zur Vervollkommnung der quantitativen Phytoplankton-Methodik. Mitt. Int. Ver. Theor. Angew. Limnol. 9: 1-38. (in German).

Vollenweider, R. A. \& J. Kerekes. 1982. Eutrophication of waters. Monitoring, assessment and control. OECD Cooperative programme on monitoring of inland waters (Eutrophication control). Environment Directorate, OECD, Paris

Vörös, L., A. Mózes \& B. Somogyi, 2009. A five-year study of autotrophic winter picoplankton in Lake Balaton, Hungary. Aquatic Ecology 43: 727-734.

Wetzel, R. G., 2001. Lymnology. Lake and River Ecosystems. Academic Press, San Diego.

Wetzel, R. G. \& G. E. Likens, 2000. Composition and biomass of phytoplankton. In Wetzel, R. G. \& G. E. Likens (eds), Limnological Analyses. Springer, New York: 139-165.

Yuan, L. L. \& A. I. Pollard, 2018. Changes in the relationship between zooplankton and phytoplankton biomasses across a Eutrophication gradient. Limnology Oceanography 63: 2493-2507.

Publisher's Note Springer Nature remains neutral with regard to jurisdictional claims in published maps and institutional affiliations. 